Sмiтн, W. K. (1958). J. gen. Microbiol. 18, 42-47

\title{
Chromatographic Examination of the Products of Digestion of Pectic Materials by Culture Solutions of Plant Pathogenic and other Bacteria
}

\author{
By W. K. SMITH \\ Imperial Chemical Industries Ltd., Akers Research Laboratories, \\ Welwyn, Hertfordshire
}

SUMMARY: Solutions containing pectic materials were digested by solutions from cultures of 25 bacteria and examined chromatographically for breakdown products. Galacturonic acid and oligo-uronides were found with soft-rot Erwinia spp., Xanthomonas campestris, Pseudomonas marginalis, Bacillus polymyxa and Klebsiella aerogenes (galacturonic acid only).

In an accompanying paper (Smith, 1958) the results of screening a number of cultures of bacteria for production of pectic enzymes have been described. To obtain further information on the nature of the enzymes concerned the products of digestion of pectic materials by some of the bacteria were examined by paper partition chromatography.

\section{METHODS}

Cultures were grown in SM1 medium (Smith, 1958) and sampled at various times. The supernatant fluid after centrifuging was added to substrates of pectin or pectic acid at $\mathrm{pH} \mathrm{7.5}$ or $\mathbf{5 . 5}$ as for viscosity tests-in some cases the proportion of culture was increased from $7 \frac{1}{2}$ to $10 \%$-and incubated for periods of up to 3 days. In most cases loss of viscosity was practically complete in the first $24 \mathrm{hr}$. but further diminution in the ethanolic precipitate occurred on longer incubation.

Samples for chromatography were concentrated and purified because tailing of the crude digests made identification of spots on the chromatograms uncertain. The following simple procedure purified the solutions by removing higher uronides and some unidentified material which practically coincided with galacturonic acid on the chromatograms. Absolute ethanol (5 ml.) was mixed with $5 \mathrm{ml}$. of digest and the precipitated colloidal material centrifuged off. The calcium salts of the low oligo-uronides were then precipitated by adding a drop of $1 \% \mathrm{CaCl}_{2}$ solution and $10 \mathrm{ml}$. of absolute ethanol. The precipitate was centrifuged down, drained and suspended in $1 \mathrm{ml}$. of distilled water. Solution was completed by adding a pinch of Amberlite I.R. 120 cation exchange resin in the hydrogen form; $0.1 \mathrm{ml}$. of this solution was spotted on the chromatogram. Marker spots on the chromatograms were (a) $5 \mu \mathrm{l}$. of a $0.5 \%(\mathrm{w} / \mathrm{v})$ solution of galacturonic acid; (b) $50 \mu \mathrm{l}$. of a solution containing galacturonic acid and di-galacturonic acid, obtained by digestion of pectic acid with fungal pectin glucosidase (PG) and purified by ethanol precipitation. 
Controls of substrate without culture filtrate were run with the test solutions, but controls of substrate + inactivated culture supernatant were omitted to obtain the maximum number of test spots on each paper. This was considered to be justified as preliminary tests had indicated that the concentrations of galacturonic acid and oligo-uronides in the culture fluids were low. Kraght \& Starr (1952) have shown that galacturonic acid can be metabolized by Erwinia carotovora and so it would not be expected to accumulate in the culture medium. The conclusion that a particular culture could degrade pectic substances to low uronides would be the same whether these uronides were derived from the culture or from subsequent digestion of a substrate solution by culture supernatant.

The solvent used was a modification of the ethyl acetate + acetic acid + water system (Jermyn \& Isherwood, 1949; Ayres et al. 1952; Demain \& Phaff, 1954; McCready \& McComb, 1933). With a mixture of equal volumes of the three components galacturonic acid moved approximately $30 \mathrm{~cm}$. when developed (descending) overnight on Whatman no. 1 paper. The di-, tri- and tetrauronides were spaced behind the galacturonic acid so that there was a constant ratio of $0 \cdot 76-0 \cdot 84$ between the distances moved by successive members of the series. After development the papers were dried, sprayed with benzidine + trichloroacetic acid reagent (Roelofsen, 1953) and heated at $90^{\circ}-105^{\circ}$ for $10 \mathrm{~min}$. Under these conditions $5 \mu \mathrm{g}$. galacturonic acid gave a definite brown spot.

\section{RESULTS}

The results are summarized in Table 1.

To confirm the presence of galacturonic acid and obtain some idea of the concentration the Dische (1947) reaction was applied, to some of the solutions used for chromatography. By comparison with standard solutions of galacturonic acid it was estimated that some $10 \%$ of the original pectic material was present as monomer or dimer in digests by soft-rot Erwinia spp., with individual cultures ranging from $2 \%$ to $20 \%$.

\section{DISCUSSION}

These results show that, like fungi and yeasts, some bacteria produce enzymes capable of breaking down pectic substances to galacturonic acid and the low oligo-uronides. This faculty is distributed similarly to the ability to produce pectin methyl esterase (PME) but there are some exceptions-galacturonic acid is liberated in the absence of detectable PME by one strain of Erwinia carotovora and by Bacillus polymyxa, Klebsiella aerogenes, Pseudomonas marginalis, $\boldsymbol{P}$. medicaginis, whilst the strain of $X$ anthomonas vasculorum which produced PME did not liberate low uronides.

Pectic enzymes produced by the soft-rot Erwinia spp. Kraght \& Starr (1953) have shown that Erwinia carotovora produces PME and PG activity which, by measurement of increase in reducing power, has a $\mathrm{pH}$ optimum of 5.8: the viscosity and ethanol precipitability of pectin solutions were also 
Table 1. Production of galacturonic acid and low uronides from pectic substances by various bacteria

\begin{tabular}{|c|c|c|c|}
\hline & 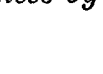 & Production of (1) & $\begin{array}{l}\text { Galacturonides } \\
\text { liberated }\end{array}$ \\
\hline Organisms & strains & Glycosidase Esterase & Higher (2) \\
\hline
\end{tabular}

Erwinia carotovora, (3) etc.

E. carotovora

Xanthomonas campestris

$\boldsymbol{X}$. vasculorum

E. raphontici

Klebsiella aerogenes

Pseudomonas marginalis

P. medicaginis

$P$. syringae

Non-pathogenic Pseudomonas sp.

X. papavericola

Flavobacterium sp.

Bacillus polymyxa

B. subtilis

E. tracheiphila

Escherichia coli

Corynebacterium flaccumfaciens

$\begin{array}{llll}+ & + & + & + \\ + & - & + & + \\ + & + & + & + \\ + & + & - & - \\ + & - & - & - \\ + & - & + & - \\ + & - & + & + \\ + & - & + & + \\ + & - & - & - \\ + & - & - & - \\ + & - & - & - \\ + & - & - & - \\ + & - & + & + \\ + & - & - & - \\ - & - & - & - \\ - & - & - & - \\ - & - & - & -\end{array}$

(1) (Smith, 1958).

(2) May include di-, tri-, tetra-, penta-galacturonic acids.

(3) Includes E. aroideae, E. atroseptica, E. phytophthora.

destroyed. Wood (1951, 1955 a) has described preparations of $E$. aroideae which destroyed the viscosity of pectin and pectic acid most rapidly at $\mathrm{pH}$ values above 7 . They also liberated reducing groups but no galacturonic acid could be detected in the products and PME was absent or negligible in amount. In the present investigations (Smith, 1958) no qualitative differences have been found in the pectic enzymes produced by the various soft-rot bacteria$E$. aroideae, E. atroseptica, E. carotovora, E. phytophthora; all produce PME, destroy the viscosity and ethanol precipitability of pectin and pectic acid solutions and liberate galacturonic acid from pectic substances. Destruction of viscosity is more rapid at $\mathrm{pH} \mathbf{7 \cdot 5}$ than $\mathbf{5 \cdot 5}$, but, in some cases, activity at the lower $\mathrm{pH}$ is sufficient to suggest the presence of $\alpha$-PG. Whilst it thus appears that the soft-rot Erwinia spp. produce two pectin glycosidases the possibility remains that the same enzyme might have different $\mathrm{pH}$ optima depending upon the method of assay. The results of Phaff \& Demain (1956) with a purified yeast polygalacturonase (YPG) are relevant in this connexion. YPG hydrolyses pectic acid with an optimum $\mathrm{pH}$ of $4 \cdot 4$ at which value tetra-galacturonic acid and tri-galacturonic acid are attacked very slowly. At pH 3.5 the breakdown of these uronides under the influence of YPG is accelerated many fold. As a result lowering the $\mathrm{pH}$ from 4.5 to 3.5 will decrease the rate at which the viscosity of a pectic acid solution is destroyed and increase the rate of liberation of reducing substances.

Role of pectin methyl esterase in soft-rot diseases. The function of PME in rotting is not so obvious as that of PG particularly when the pathogen produces glycosidases capable of attacking pectic substances of both high- and 
low-methoxyl content. Nevertheless, it is possible that PME, directly and indirectly, plays an important part in the rotting process and might even, as its restricted distribution suggests, determine the difference between pathogenicity and non-pathogenicity.

Indirect effect of PME. Whether or not an infection develops into a lesion is determined by the relative speeds of the pathogenic processes of the parasite and the defensive mechanisms of the host. Anything favouring the former will increase the probability that a rot will become established. Lapwood (1957) has shown that one difference between soft-rot Erwinia spp. and some saprophytic PG-producing bacteria is the greater growth rate of the former in potato media. If, in addition, the action of the PG of the pathogens was accelerated this difference would be enhanced. Wood (1955 $a$ ) suggested that highand low-methoxyl pectins are degraded at similar rates by PG from $E$. aroideae but the experimental figures he gave indicate important differences. Hydrolysis, relative to the theoretical maximum possible increase in reducing power, was: at 5 min., pectin, $1.7 \%$; sodium pectate, $10 \cdot 0 \%$; at $24 \mathrm{hr}$., pectin, $19.1 \%$; sodium pectate, $\mathbf{3 7 \cdot 4} \%$; after this little further increase occurred. These differences are hardly negligible but, in fact, indicate that demethylation increases the susceptibility of the substrate to enzymic hydrolysis. The final extent of degradation is nearly doubled, and, more significant as far as rotting is concerned, initial breakdown is more rapid.

Direct effect of pectin methyl esterase. Whilst direct evidence is lacking the probable result of de-esterification of the plant pectic colloids would be to reduce their water-holding capacity (Kertesz, 1951, p. 184; Deuel \& Solms, 1954) resulting in a condition similar to water-soaking. This has been shown (Fernando \& Stevenson, 1952; Gregg, 1952; Lapwood, 1957) to render vegetable tissue susceptible to attack by bacteria which do not produce rots in normal tissue, e.g. Bacillus subtilis, Pseudomonas syringae, Flavobacterium sp. —organisms which differ from the soft-rot Ervinia spp. in not producing PME (Smith, 1958).

Role of pectin glycosidase in soft-rot diseases. Destruction of the colloidal pectic material of plant tissue plays an obvious part in soft-rotting and this aspect has been discussed many times (see, for example, Wood, 1955b). Galacturonic acid, which is probably liberated, can be metabolized by $E$. carotovora (Kraght \& Starr, 1952).

Extent of glycosidase action. The figure given by Wood (1955a) for the ultimate extent of hydrolysis of pectic acid, $37 \%$, is interesting in indicating that the final products have an average size of $2 \cdot 7$ galacturonic acid units. If no galacturonic acid is present these products must consist of a mixture equivalent to $30 \%$ di-galacturonic acid and $70 \%$ tri-galacturonic acid (by number). If higher polymers are present the proportion of di-galacturonic acid molecules must be increased considerably. This suggests that the extent of hydrolysis is limited not by some hypothetical unit in the pectic molecule but by a restriction on the capabilities of the enzyme, e.g. that, like $\beta$-amylase, it cannot attack a terminal glycoside bond. In view of these considerations Wood's choice of the term 'depolymerase' is unfortunate, despite his reservation 
that it 'in no way attempts to specify the way in which the enzymes act': more particularly so since the enzyme to which Kertesz (1949) applied the term did not attack high-methoxyl pectin but required the prior action of PME and was inhibited by calcium (McColloch \& Kertesz, 1948). Schubert's term 'pectinglycosidase' seems to be more appropriate, at least until the mode of action of the various enzymes is more exactly understood.

Organisms other than soft-rot Erwiniae. Little is known about the pectic conversions of the other bacteria examined, and it is difficult to assess the significance of the chromatographic findings at present. In the case of the two strains of Klebsiella aerogenes only small amounts of galacturonic acid and no higher uronides were detected. The rate at which they reduced the viscosity of pectic solutions was slower than that of the soft-rot erwinias so that it seems possible that their enzymes operate by stepwise removal of terminal units rather than by random fission of the molecule. They would thus be similar to the galacturogenic polygalacturonase of Aspergillus niger (Saito, 1955).

I am grateful to Dr Jean Malcolmson, Dr J. Kleczkowski, Dr A. Paton, Dr S. B. Thomas, Dr W. J. Dowson, Dr J. E. Crosse, Dr D. H. Lapwood, Dr G. M. Wickens, The National Collection of Industrial Bacteria and the National Collection of Plant Pathogenic Bacteria for providing cultures, and to Mrs P. B. Coomber and Mr G. F. Richmond for technical assistance.

\section{REFERENCES}

Ayres, A., Dingle, J., Phipps, A., Reid, W. W. \& Solomons, G. L. (1952). Enzymic degradation of pectic acid and the complex nature of polygalacturonase. Nature, Lond. 170, 834.

Demarn, A. L. \& Phaff, H. J. (1954). Hydrolysis of the oligogalacturonides and pectic acid by yeast polygalacturonase. J. biol. Chem. $210,381$.

Deuel, H. \& Solms, J. (1954). Observations on pectic substances. In Natural plant hydrocolloids. Amer. Chem. Soc. Advanc. Chem. Series, 11, 62.

Dische, Z. (1947). A new specific colour reaction of hexuronic acids J. biol. Chem. $167,189$.

Fernando, M. \& Stevenson, G. (1952). Studies in the physiology of parasitism. XVI. Effect of the condition of potato tissue, as modified by temperature and water content, upon attack by certain organisms and their pectinase enzymes. Ann. Bot., Lond. 16, 103.

GregG, M. (1952). Studies in the physiology of parasitism. XVII. Enzyme secretion by strains of Bacterium carotovorum and other pathogens in relation to parasitic vigour. Ann. Bot., Lond. 16, 235.

Jermyn, M. A. \& Isherwood, F. A. (1949). Improved separation of sugars on the paper partition chromatogram. Biochem. J. 44, 402.

KenTEsz, Z. I. (1949). Recent developments of practical significance in the field of pectic enzymes. Food. Tech. Campaign, 3, 94.

Kertesz, Z. I. (1951). The Pectic Substances. New York: Interscience Publishers Inc.

Kraght, A. J. \& Stark, M. P. (1952). Fermentation of galacturonic acid and glucose by a strain of Ervinia carotovora. J. Bact. 64, 259.

Kraght, A. J. \& Starr, M. P. (1953). Pectic enzymes of Erwinia carotovora. Arch. Biochem. Biophys. 42, 271. 
LAPwOoD, D. H. (1957). Studies in the physiology of parasitism. XXIII. On the parasitic vigour of certain bacteria in relation to their capacity to secrete pectolytic enzymes. Ann. Bot., Lond. 21, 167.

McColloch, R. J. \& Kertesz, Z. I. (1948). An unusually heat-resistant pectolytic factor from tomatoes. Arch. Biochem. 17, 197.

McCready, R. M. \& McComb, E. A. (1953). Course of action of polygalacturonase on polygalacturonic acids. J. Agric. Fd Chem. 1, 1165.

Phaff, H. J. \& Demain, A. L. (1956). The unienzymatic nature of yeast polygalacturonase. J. biol. Chem. $218,875$.

Roelofsen, P. A. (1953). Polygalacturonase activity in yeast, Neurospora and tomato extract. Biochem. biophys. Acta, 10, 410.

Sarto, H. (1955). Pectic glycosidases of Aspergillus niger. J. gen. appl. Microbiol. $1,35$.

SмIтн, W. K. (1958). A survey of the production of pectic enzymes by plant pathogenic and other bacteria. J. gen. Microbiol. 18, 33.

Wood, R. K. S. (1951). Pectic enzymes produced by Bacterium aroideae. Nature, Lond. 167, 771.

Woon, R. K. S. (1955a) Studies in the physiology of parasitism. XVIII. Pectic enzymes secreted by Bacterium aroideae. Ann. Bot., Lond. 19, 1.

Woon, R. K. S. $(1955 b)$. Pectic enzymes secreted by pathogens and their role in plant infection. In Mechanisms of Microbial Pathogenicity. Symp. Soc. gen. Microbiol. 5, 263.

(Received 27 May 1957) 